\title{
Bioassays and Inactivation of Prions
}

\author{
Kurt Giles, ${ }^{1,2}$ Amanda L. Woerman, ${ }^{1,2}$ David B. Berry, ${ }^{1}$ and Stanley B. Prusiner ${ }^{1,2,3}$ \\ ${ }^{1}$ Institute for Neurodegenerative Diseases, Weill Institute for Neurosciences, University of California, \\ San Francisco, San Francisco, California 94158 \\ ${ }^{2}$ Department of Neurology, University of California, San Francisco, San Francisco, California 94158 \\ ${ }^{3}$ Department of Biochemistry and Biophysics, University of California, San Francisco, San Francisco, \\ California 94158 \\ Correspondence: stanley.prusiner@ucsf.edu
}

The experimental study of prions requires a model for their propagation. However, because prions lack nucleic acids, the simple techniques used to replicate bacteria and viruses are not applicable. For much of the history of prion research, time-consuming bioassays in animals were the only option for measuring infectivity. Although cell models and other in vitro tools for the propagation of prions have been developed, they all suffer limitations, and animal bioassays remain the gold standard for measuring infectivity. A wealth of recent data argues that both $\beta$-amyloid $(A \beta)$ and tau proteins form prions that cause Alzheimer's disease, and $\alpha$ synuclein forms prions that cause multiple system atrophy and Parkinson's disease. Cell and animal models that recapitulate some of the key features of cell-to-cell spreading and distinct strains of prions can now be measured.

$\mathrm{T}_{\mathrm{t}}^{\mathrm{h}}$ he unusual resistance of PrP prions to inactivation was an early indication that they represented a different class of infectious agents to bacteria or viruses. Incomplete inactivation of PrP prions has led to medically induced, or iatrogenic, Creutzfeldt-Jakob disease (CJD). Worldwide, the number of elderly individuals who undergo surgery has increased, and because of the unusually long asymptomatic phase of CJD, there are a growing number of cases in which surgical instruments are used on an asymptomatic patient and then reused repeatedly before a CJD diagnosis is confirmed. Recent data suggesting the potential for iatrogenic transmission of $\beta$-amyloid $(A \beta)$ amyloidosis has raised renewed interest in the field of prion inactivation.

\section{BIOASSAY OF PrP PRIONS}

The first reports of sheep scrapie are thought to date from the 18th century, and the description of an analogous disease in humans was reported early in the 20th century. However, the first successful transmission of these diseases to animals, in the 1930s and 1960s, respectively, marked the start of the experimental era of prion research. Initial attempts to transmit sheep scrapie were unsuccessful, likely because of insufficient observation periods. When transmission of sheep scrapie to sheep was finally observed, it was $>1$ yr after inoculation (Cuillé and Chelle 1936); transmission of sheep scrapie to goats required $>2$ yr (Cuillé and Chelle 1939). Similarly, experimental transmission of

Editor: Stanley B. Prusiner

Additional Perspectives on Prion Biology available at www.cshperspectives.org

Copyright (C) 2017 Cold Spring Harbor Laboratory Press; all rights reserved; doi: 10.1101/cshperspect.a023499

Cite this article as Cold Spring Harb Perspect Biol 2017;9:a023499 
K. Giles et al.

kuru and CJD to chimpanzees took $\sim 2 \mathrm{yr}$ following intracerebral inoculation (Gajdusek et al. 1966; Gibbs et al. 1968). Early attempts to transmit other neurodegenerative diseases produced ambiguous results, and it has only been in the last decade that a wealth of data has accumulated to support the idea that most, if not all, neurodegenerative diseases are caused by proteins that change their conformation to an aggregation-prone state and become self-templating (i.e., prions) (Prusiner 2012).

Although the bioassays originally performed in large animals for the prototypical prions were cumbersome, important information was obtained. Bioassays in sheep demonstrated the resistance of prions to formalin and heat (Gordon 1946; Stamp et al. 1959; Pattison and Millson 1960). In addition, transmission of sheep scrapie to goats provided the first evidence of prion strains, with inoculated animals showing one of two distinct phenotypes: "drowsy" owing to the lethargy manifest during the clinical phase of scrapie, or "hyper" because these animals were highly irritable and easily aroused (Pattison and Millson 1961). The difficulties of performing such experiments are highlighted by the calculation of prion titer. An endpoint titration, in which serially diluted samples were inoculated into naïve animals, required an entire herd of goats to quantify the concentration of prions in a single sample (Pattison 1966).

\section{Transmission of Scrapie to Rodents}

The experimental transmission of scrapie to rodents marked a turning point in prion research, enabling many new experimental studies to be performed. The time to disease onset following inoculation (incubation period) for goat-passaged sheep scrapie in mice was $\sim 1$ yr (Chandler 1961), but subsequent serial passage in mice shortened and stabilized incubation periods to $\sim 4$ mo (Chandler 1962).

Another important advance came with transmission of PrP prions to hamsters. Inoculation of the "Chandler isolate" of mouse-passaged prions into hamsters, followed by serial passage, resulted in incubation periods as short as $\sim 60 \mathrm{~d}$ (Kimberlin and Walker 1977). The shorter incubation periods and the finding that prion titers in the brains of terminal hamsters were $\sim 10$-fold higher than in mice made this the preferred model despite the increased cost of housing hamsters over mice.

\section{Incubation-Time Assay}

Despite the advances of the prion-infected hamster model, endpoint titrations were still time consuming and costly. Typically, ten 10fold dilutions of brain homogenate were each inoculated into four to six hamsters, and the animals were monitored for at least $6 \mathrm{mo}$. Based on observations that the time interval from inoculation to onset of illness increased as the prion dose decreased (Eklund et al. 1963; Hunter et al. 1963), experiments were performed to determine whether incubation time could be used to reliably measure titer. Extensive studies showed that the measurement of incubation periods predicted prion titer with a similar precision to that obtained by endpoint titration, but this new approach required less time and fewer animals (Prusiner et al. 1980, 1982).

\section{Transgenic Mice}

The generation of transgenic ( Tg) mice overexpressing mouse or hamster $\operatorname{PrP}$ genes provided animal models with even shorter incubation times than wild-type (WT) hamsters (Prusiner et al. 1990; Carlson et al. 1994). When mice were developed in which the endogenous mouse $\operatorname{PrP}$ gene was ablated $\left(\operatorname{Prnp}^{0 / 0}\right.$ mice), new opportunities for transgenic mouse studies were presented. $\operatorname{Prnp}{ }^{0 / 0}$ mice did not develop prion disease and did not support prion replication (Büeler et al. 1993). Importantly, mice expressing human PrP on a WT mouse PrP background were resistant to infection with CJD prions, but became susceptible when backcrossed to the $\operatorname{Prn} p^{0 / 0}$ background (Telling et al. 1995). Transgenes encoding PrP from a range of species have subsequently been used to bioassay various natural and passaged prion strains and to study transmissibility between species (for review, see Watts and Prusiner 2014). 


\section{Cultured Cells}

Although the gold standard for measuring prion infectivity remains animal bioassays, typically in WT or Tg rodents, these studies are time consuming and expensive. The finding that the amount of PrP remaining after limited proteolysis with proteinase $\mathrm{K}(\mathrm{PK})$ closely correlates with prion infectivity (McKinley et al. 1983) provided a simple tool to measure the diseasecausing conformation of the prion protein, $\mathrm{PrP}^{\mathrm{Sc}}$, and helped to identify cell models capable of propagating prions. Mouse neuroblastoma cells (N2a) were shown to propagate mousepassaged sheep scrapie derived from the Chandler isolate (Race et al. 1987; Butler et al. 1988); the resulting prion-infected cells are referred to as ScN2a. Subsequently, N2a cells were shown to propagate a subset of prion strains, including 22L and 139A but not ME7, 87V, or 22A (Bosque and Prusiner 2000; Nishida et al. 2000). A limited number of other cell lines were identified that stably propagate $\operatorname{PrP}$ prions, including the mouse hypothalamic neural cell line GT1 (Schätzl et al. 1997) and the fibroblast-derived line 3T3 (Vorberg et al. 2004). Rat pheochromocytoma cells (PC12) have been reported to propagate mouse prions (Rubenstein et al. 1984, 1992), but the biology of this system remains unclear. A rigorous study of the susceptibility of N2a and Cath.a-differentiated (CAD) cell subclones to multiple prion strains identified the CAD5 line with the broadest PrP strain sensitivity reported to date (Mahal et al. 2007). The differential sensitivities of cell lines were used to develop a scrapie cell panel assay to discriminate between prion strains (Mahal et al. 2007).

Despite the success of PK-based approaches in identifying cell models, subsequent studies have revealed that a portion of $\mathrm{PrP}^{\mathrm{Sc}}$ can be $\mathrm{PK}$ sensitive, depending on the strain (Safar et al. 1998); in CJD, up to $90 \%$ of $\mathrm{PrP}^{\mathrm{Sc}}$ was found to be PK-sensitive (Safar et al. 2005). It is therefore important that any findings identified in cell models are validated by animal bioassays.

\section{Cell-Free Assays}

The "protein-only" hypothesis of prion propagation suggested that it should be theoretically possible to model this process in vitro. The first substantive step toward this goal was the partial denaturation of $\mathrm{PrP}^{\mathrm{Sc}}$ and the incorporation of new cellular prion protein, $\mathrm{PrP}^{\mathrm{C}}$, into a protease-resistant conformation (Kocisko et al. 1994). This technique was used to study the molecular level of transmission barriers due to differences in primary structure (Kocisko et al. 1995). However, conversion was substoichiometric, in contrast to the exponential growth of $\mathrm{PrP}^{\mathrm{Sc}}$ in vivo. It is possible that this difference reflected linear growth of $\mathrm{PrP}^{\mathrm{Sc}}$, as opposed to repeated fragmentation and growth that would be required for more rapid prion propagation. Subsequent studies to fragment growing prion aggregates using sonication led to the protein misfolding cyclic amplification (PMCA) assay (Saborio et al. 2001). Refinement of the PMCA technology showed that in addition to replicating PK-resistant PrP, infectious $\mathrm{PrP}^{\mathrm{Sc}}$ could be generated (Castilla et al. 2005). Parallel studies using shaking to fragment $\mathrm{PrP}^{\mathrm{Sc}}$ seeds led to the amyloid seeding assay (ASA) (Colby et al. 2017) and the quaking-induced conversion (QuIC) assay (Atarashi et al. 2008); however, the ASA and QuIC methodologies have yet to demonstrate the replication of prion infectivity.

\section{BIOASSAYS FOR NON-PrP PRIONS}

\section{Animal Assays}

Alzheimer's disease $(\mathrm{AD})$ is characterized by neuropathological aggregates of two proteins: $\mathrm{A} \beta$ and tau. Experimental models for iatrogenic $\mathrm{A} \beta$ amyloidosis have been developed based on intracerebral inoculation of brain homogenates from $\mathrm{AD}$ patients into $\mathrm{Tg}$ mice producing human A $\beta$ (Kane et al. 2000; Meyer-Luehmann et al. 2006) and into nonhuman primates (Baker et al. 1994; Ridley et al. 2006).

Because $A \beta$ amyloidosis does not lead to a lethal phenotype, these animals were euthanized for neuropathological analysis to assess transmission and disease progression. We previously showed that in $\mathrm{PrP}$ prion diseases, progression could be monitored in vivo using a luciferase reporter driven by the glial fibrillary acid protein (GFAP) promoter (Tamgüney et al. 
K. Giles et al.

2009). We demonstrated that GFAP upregulation correlated with $A \beta$ load in two Tg mouse lines and that upregulation of GFAP could be monitored in vivo in these mice (Watts et al. 2011). Using this paradigm, we were able to demonstrate that synthetic $A \beta$ alone was sufficient to induce $A \beta$ amyloidosis in a susceptible Tg mouse line (Stöhr et al. 2012). Moreover, we showed that the $A \beta$ isoform-specific phenotypes from familial and sporadic $\mathrm{AD}$ could be serially propagated in vivo, defining various $A \beta$ prion strains (Watts et al. 2014). Different synthetic $A \beta$ strains were also induced by varying the folding conditions, which resulted in different neuropathological phenotypes following intracerebral inoculation into Tg mice (Stöhr et al. 2014; for review, see Watts and Prusiner 2016).

Seeded aggregation of tau has also been modeled in Tg mice, most notably in one line expressing full-length human WT tau, termed ALZ17 (Probst et al. 2000). Inoculation of ALZ17 mice with brain homogenate from aged $\mathrm{Tg}$ mice expressing human tau with the disease-causing P301S mutation induced neurofibrillary tangles along with neuropil threads and coiled bodies (Clavaguera et al. 2009). Subsequent studies demonstrated that inoculating tau oligomers isolated from $\mathrm{AD}$ patient samples into the ALZ17 mice resulted in tau neuropathology similar to that seen in $\mathrm{AD}$ patients ( $\mathrm{La}-$ sagna-Reeves et al. 2012). Following the initial transmission of human tau prions to $\mathrm{Tg}$ mice, inoculation experiments using brain homogenate from patient samples yielded transmission of distinct tau neuropathologies in the ALZ17 mice reminiscent of the neuropathologies associated with each disease inoculated (Clavaguera et al. 2013). Using a different $\mathrm{Tg}$ mouse line expressing tau with the P301S mutation, termed PS19 (Yoshiyama et al. 2007), synthetic tau fibrils were used to induce progressive tau pathology (Iba et al. 2013; for review, see Clavaguera et al. 2016).

Parkinson's disease (PD), dementia with Lewy bodies (DLB), and multiple system atrophy (MSA) are neuropathologically characterized by aggregates of hyperphosphorylated $\alpha$ synuclein. Multiple Tg mouse models, many of which harbor mutations associated with fa- milial PD, have been developed for what are referred to collectively as the synucleinopathies. One of these Tg lines expresses human $\alpha$-synuclein with the mutation A53T driven by the PrP promoter, termed M83 (Giasson et al. 2002). Homozygous $\mathrm{M} 83^{+/+}$mice develop spontaneous disease at $\sim 1 \mathrm{yr}$, at which point their brains contain extensive aggregated $\alpha$-synuclein. Brain homogenate from aged $\mathrm{M} 83^{+/+}$mice induced synucleinopathy and accelerated disease onset when inoculated into young $\mathrm{M}^{2} 3^{+/+}$mice (Luk et al. 2012b; Mougenot et al. 2012). Similarly, intracerebral inoculation of fibrils formed from synthetic $\alpha$-synuclein accelerated disease onset in ${\mathrm{M} 83^{+/+}}$mice (Luk et al. 2012b) and even induced neuropathological changes in WT mice (Luk et al. 2012a). Likewise, brain homogenate from an aged $\mathrm{Tg}$ mouse expressing human $\alpha$-synuclein with the A30P mutation induced synucleinopathy when inoculated into young mice of the same line (Schweighauser et al. 2015). Lewy body extracts from PD patient samples induced $\alpha$-synuclein pathology in WT mice and monkeys, but no behavioral deficits were observed (Recasens et al. 2014).

To study MSA patient samples, we performed intracerebral inoculations of brain homogenate in hemizygous $\mathrm{M} 83^{+/-}$mice, which do not develop spontaneous disease. Remarkably, initial studies with brain homogenates from two MSA patients induced a lethal phenotype in the mice $\sim 4$ mo after inoculation, along with robust $\alpha$-synuclein pathology throughout the hindbrain and portions of the mesencephalon (Watts et al. 2013). Subsequent inoculation of samples from 12 additional patients found that all 12 transmitted a lethal synucleinopathy, whereas control and PD patient samples had no effect (Prusiner et al. 2015; for reviews, see Hasegawa et al. 2016 and Woerman et al. 2016).

\section{Cell Assays}

Modeling the aggregation of other prions in cells has proven much simpler than identifying cell lines that replicate PrP prions. Expressing a fusion protein consisting of the repeat domain of human tau fused to yellow fluorescent protein (YFP) in human embryonic kidney (HEK) 
cells enabled tau aggregation to be monitored by the development of microscopic YFP puncta (Holmes and Diamond 2017). Of 29 samples from human tauopathies, 21 induced aggregate formation when incubated with these cells. Moreover, aggregate morphologies appeared to correlate with distinct disease states (Sanders et al. 2014).

Developing a high-throughput assay with this cell line to detect tau prions, we adapted the model to a 384-well-plate format to facilitate automated imaging and analysis using the IN Cell Analyzer 6000 (Woerman et al. 2015). Cells incubated with crude brain homogenate from either control or progressive supranuclear palsy (PSP) patient samples yielded no significant differences when we tested the samples under the new assay conditions. However, after isolating aggregated protein from the patient samples by precipitation with sodium phosphotungstate (PTA), tau prions from the PSP patient samples induced aggregates in $\sim 61 \%$ of the cells, whereas the control sample had no effect (Woerman et al. 2015).

Using an analogous concept, we developed a separate line of HEK cells capable of selectively detecting $\alpha$-synuclein prions isolated from MSA patient samples (Woerman et al. 2015). These cells express full-length $\alpha$-synuclein with the A53T mutation fused to YFP, which formed bright aggregates in the presence of recombinant $\alpha$-synuclein prions. When we incubated the cells with crude brain homogenate from control and MSA patient samples, the MSA patient samples had no effect on aggregate formation after $4 \mathrm{~d}$. However, PTA-precipitated $\alpha$-synuclein prions from the MSA patient samples robustly infected the $\alpha$-synuclein-YFP cells. This response was specific to MSA; PTAprecipitated aggregates from $\mathrm{PD}, \mathrm{DLB}$, and Parkinson's disease with dementia did not infect the cells, although the concentration of $\alpha$-synuclein in the samples was similar to that in the MSA patient samples (Woerman et al. 2016). Importantly, we also found that the rate of infection in the cell assay correlated with the incubation time in the Tg mouse transmission studies, providing a faster and less-expensive measure of MSA prion titer (Prusiner et al. 2015).

Notably, all of the cellular assays described above have demonstrated specificity for homotypic seeding. The tau-YFP cells are not infected by $\alpha$-synuclein or A $\beta$ prions. The $\alpha$-synuclein-YFP cells are not infected by tau or $A \beta$ prions (Woerman et al. 2015). This specificity confers the ability to rapidly bioassay distinct prions in vitro.

\section{Cell-Free Assays}

The QuIC paradigm has recently been applied to $\alpha$-synuclein (Fairfoul et al. 2016; Hughson et al. 2016). One implementation of the assay demonstrated sufficient sensitivity to detect seeding from the cerebrospinal fluid of patients with PD or DLB (Fairfoul et al. 2016). Additionally, the QuIC assay has been applied to measure the seeding of tau prions (Hughson et al. 2016).

\section{INACTIVATION OF PRIONS}

Because prion propagation involves templatedirected refolding of an endogenous protein, prions have the amino acid sequence of the host in which they were propagated. For example, human prions passaged in WT mice produce prions with the mouse PrP sequence. In other words, in interspecies infection, the prions that replicate in the host brain are not the same as those that initiate replication. This scenario is profoundly different from that which occurs during a bacterial or viral infection and is crucial in developing and implementing appropriate infection control procedures.

Assumptions about the nature of infectious prions and a poor appreciation of potential strain differences confound much of the early literature on prion inactivation. Even the recent literature is not free of such errors, with authors referring to "human prion strains" when discussing mouse-passaged human prions, and prion disinfection guidelines based on experiments in which the exact nature of the prion strain under examination is not clearly defined. Care must also be taken in the terminology used 
K. Giles et al.

to describe inactivation. Sterilization is a widely used term in infection control and is typically defined as the complete elimination of microorganisms. In practice, "elimination" is based on the sensitivity of the detection system used to replicate any residual infectivity. In prion biology, the lack of reliable ex vivo methods for the replication of infectivity means that bioassays in animals are required; even then, they may be of limited sensitivity compared with that which can be grown in a bacterial or viral culture. Experiments starting with a low prion titer or using an insensitive detection method can lead to claims of prion "sterilization" that may not actually eliminate the potential for infection.

The unusual resistance to inactivation of infectious prions responsible for scrapie in sheep was first observed eight decades ago. In 1935 , a large-scale vaccination program was implemented in the United Kingdom against the louping-ill virus. Sheep were immunized with a $10 \%$ homogenate prepared from the brain, spinal cord, and spleen of sheep infected with louping-ill, which was treated with $0.35 \%$ formalin. Intracerebral inoculation into mice and sheep demonstrated that this procedure inactivated the virus. Although the immunization campaign proved successful in reducing the incidence of louping-ill, $2.5 \mathrm{yr}$ into the program, scrapie appeared in sheep immunized with a single batch of the vaccine. These cases were ultimately attributed to tissue from asymptomatic scrapie-infected sheep included in that particular batch. More important, these cases demonstrated that scrapie prions were resistant to the formalin treatment that inactivated the louping-ill virus (Gordon 1946). Analogously, incomplete prion inactivation has led to iatrogenic CJD transmission. For example, standard hot-air sterilization at $180^{\circ} \mathrm{C}$ for $2 \mathrm{~h}$ was insufficient to inactivate CJD prions, leading to subsequent iatrogenic transmission via brain surgery (Poisson et al. 1980; Taylor 1999). Incomplete prion inactivation also led to the bovine spongiform encephalopathy (BSE) epidemic in Europe. The emergence and spread of BSE arose following changes in the rendering process that led to exposure of the resultant meat and bone meal to lower temperatures for shorter periods, recycling prions back into cattle and, ultimately, human food supplies (Wilesmith et al. 1988).

Experimental transmission studies using sheep scrapie demonstrated that drying brain and spinal cord samples before storing them at $0^{\circ} \mathrm{C}$ did not eliminate infectivity (Wilson et al. 1950). Subsequent studies reported that infectivity remained following storage at $40^{\circ} \mathrm{C}$ for several years or after heating samples to $100^{\circ} \mathrm{C}$ for up to $8 \mathrm{~h}$ (Stamp et al. 1959). Moreover, incubation with acetylethyleneimine for a period $50 \%$ longer than that known to completely inactivate 12 different viruses, followed by lyophylization and reconstitution, did not entirely inactivate scrapie prions (Stamp et al. 1959).

Mouse-passaged sheep scrapie was shown to be highly resistant to ultraviolet irradiation, leading to the proposition that it might not contain a nucleic acid (Alper et al. 1966, 1967). Further experiments showed resistance to inactivation by various chemicals including glutaraldehyde, peracetic acid, or ethanol, and to extended heating, including at $160^{\circ} \mathrm{C}$ for $24 \mathrm{~h}$ (Dickinson and Taylor 1978). Additional independent transmissions of sheep scrapie to mice and serial passaging experiments led to the identification of multiple strains of mouse-passaged scrapie, each of which differed in its biological properties, including its resistance to inactivation (Dickinson and Taylor 1978).

Because of its high titer and short incubation periods, the hamster-passaged prion strain Sc237, also known as $263 \mathrm{~K}$, became widely used in prion inactivation studies. Treatment of the Sc237 strain with a variety of nonionic and nondenaturing ionic detergents did not alter its infectivity. In contrast, the denaturing detergent sodium dodecyl sulfate (SDS) inactivated Sc237 prions in a concentration-dependent manner (Prusiner et al. 1980). Chaotropic ions, including thiocyanate, guanadinium, and trichloroacetate, were also effective at reducing the titer of Sc237 prions (Prusiner et al. 1981a). Partial inactivation of the Sc237 strain was also achieved by chemical modification with diethylpyrocarbonate 
(McKinley et al. 1981) and by digestion with PK (Prusiner et al. 1981b).

Autoclaving at $121^{\circ} \mathrm{C}$ for $90 \mathrm{~min}$ was not sufficient to completely inactivate the Sc237 strain (Prusiner et al. 1984). Paradoxically, autoclaving at higher temperatures occasionally appeared to be less effective. For the $263 \mathrm{~K}$ strain, similar levels of inactivation were seen at temperatures up to $138^{\circ} \mathrm{C}$. However, with the mouse-passaged sheep scrapie and BSE strains $22 \mathrm{~A}$ and $301 \mathrm{~V}$, more infectivity was observed after autoclaving at $138^{\circ} \mathrm{C}$ than at $134^{\circ} \mathrm{C}$ (Taylor 1999).

\section{World Health Organization Guidelines}

Under the Communicable Disease Surveillance and Control Program, the World Health Organization convened a group of experts to establish guidelines for the care of patients with PrP prion diseases, including a list of prion inactivation procedures (World Health Organization 1999). These procedures, which include immersion of surgical instruments in $1 \mathrm{~N}$ sodium hydroxide $(\mathrm{NaOH})$ and autoclaving at $121^{\circ} \mathrm{C}$ for $30 \mathrm{~min}$, and soaking in 20,000 ppm sodium hypochlorite $(\mathrm{NaOCl})$ or $\mathrm{NaOH}$ for $1 \mathrm{~h}$ and then transferring to water and autoclaving (World Health Organization 1999), have been recommended by the U.S. Centers for Disease Control and Prevention and incorporated into hospital infection control protocols. However, these methods not only raise serious health and safety concerns, such as the handling of hot sodium hydroxide, but also can lead to pitting and corrosion of sensitive surgical instruments (Brown et al. 2005).

\section{Noncorrosive PrP Prion Inactivation}

We identified the ability of branched polyamine dendrimers to render $\mathrm{PrP}^{\mathrm{Sc}}$ in ScN2a cells sensitive to protease degradation (Supattapone et al. 1999). Additionally, we showed that their efficacy in prion-infected brain homogenate was enhanced at $\mathrm{pH} \leq 4$ (Supattapone et al. 2001). Based on these observations, we explored the susceptibility of prions to a variety of denaturants under mildly acidic conditions. Al- though SDS at neutral pH had modest ability to inactivate prions, it became highly effective when combined with acetic acid (AcOH) (Peretz et al. 2006). To quantify the changes in infectivity upon treatment, Cox models were derived from incubation periods of serially diluted brain homogenates and used to generate the equivalent $\log _{10}$ reduction in titer. At room temperature, shaking a $1 \%$ brain homogenate containing Sc237 prions with $1 \%$ SDS and $0.5 \% \mathrm{AcOH}$ reduced the titer by $>7 \log _{10}$ units. Nonetheless, infectivity was still present as evidenced by all mice succumbing to disease (Peretz et al. 2006). Increasing the concentration of the reagents and temperature improved prion inactivation. At $65^{\circ} \mathrm{C}$, using a $2 \% \mathrm{SDS}-1 \% \mathrm{AcOH}$ solution required $2 \mathrm{~h}$ to remove all detectable infectivity from the Sc237 brain homogenate; however, $4 \% \mathrm{SDS}-1 \% \mathrm{AcOH}$ at $65^{\circ} \mathrm{C}$ or $2 \%$ SDS $-1 \% \mathrm{AcOH}$ at $121^{\circ} \mathrm{C}$ inactivated all detectable prions within $30 \mathrm{~min}$ (Peretz et al. 2006).

To directly compare prion inactivation between the BSE strain and its mouse-passaged analog $301 \mathrm{~V}$, we derived Cox models for each strain. Brain homogenates from mice infected with BSE or $301 \mathrm{~V}$ prions were incubated with a range of treatments including "acidic SDS" for various times and temperatures. Treatments that showed low levels of inactivation produced similar reductions in prion titer of $301 \mathrm{~V}$ and BSE prions; however, with more stringent procedures, there were significant differences. BSE prions were $>1000$-fold more resistant to elimination by autoclaving at $134^{\circ} \mathrm{C}$ for $15 \mathrm{~min}$ than $301 \mathrm{~V}$ prions, suggesting that any extrapolation from rodent-passaged strains to their parent strain must be interpreted cautiously (Giles et al. 2008).

\section{Inactivating PrP Prions Bound to Surfaces}

All early prion inactivation studies were performed on solutions or suspensions of homogenized prion-infected tissue. To generate a more translational model for surgical instruments and machinery used in the processing of animal carcasses, researchers in the laboratory of Charles Weissmann used short sections of stainless steel suture wire as a surface for prion con- 
K. Giles et al.

tamination. These wires can be incubated in prion-infected brain homogenate, subjected to various inactivation procedures, and directly bioassayed by implantation into the brains of naïve mice (Zobeley et al. 1999). Incubation periods in mice implanted with prion-contaminated wires are longer than with standard intracerebral inoculation of brain homogenate, effectively producing a lower dynamic range in the bioassay. It is unclear whether this delay is a result of the quantity of prions bound to the surface of the $\sim 5 \mathrm{~mm}$ section of stainless steel wire compared with $30 \mu \mathrm{L}$ of $1 \%$ brain homogenate, the limited desorption of prions from a wire, or the ability of prions to initiate infection from the bound state.

Stainless steel wires incubated with the $263 \mathrm{~K}$ strain were subjected to various inactivation protocols. Caustic chemical treatments including $\mathrm{NaOCl}, \mathrm{NaOH}$, and a phenolic disinfectant were all effective at eliminating infectivity (Fichet et al. 2004). Autoclaving at $134^{\circ} \mathrm{C}$ for 18 min was only effective at removing detectable infectivity when the wires were immersed in water, but not when the wires were simply placed on a support (Fichet et al. 2004). Enzymatic cleaners alone were only partially effective (Fichet et al. 2004; Yan et al. 2004), and enzymatic cleaner in combination with vaporized hydrogen peroxide (Fichet et al. 2004) or alkaline detergent followed by hydrogen peroxide gas plasma sterilizer (Yan et al. 2004) were required to remove all detectible infectivity from the wires.

Although $2 \% \mathrm{SDS}-1 \% \mathrm{AcOH}$ at $65^{\circ} \mathrm{C}$ for $2 \mathrm{~h}$ was sufficient to eliminate all detectable Sc237 prion infectivity in brain homogenate, the majority of mice implanted with Sc237contaminated wires that were subject to the same treatment succumbed to prion disease, suggesting that prions on stainless steel surfaces are more difficult to inactivate than those in solution (Peretz et al. 2006). Similarly, procedures effective at inactivating BSE prions in solution, such as $4 \%$ SDS $-1 \% \mathrm{AcOH}$ at $65^{\circ} \mathrm{C}$ for $18 \mathrm{~h}$, were not completely effective at reducing all infectivity on BSE-contaminated wires, which required autoclaving in the presence of acidic SDS (Giles et al. 2008).

\section{Refinement of the Steel Wire Model}

The steel wire model has become widely adopted, and contamination is typically achieved by incubating the wires overnight in prion-infected brain homogenate. To model surgical procedures more closely, steel wires were transiently inserted into a brain collected from an asymptomatic prion-infected mouse. Wires that contacted infectious brain tissue for as little as $5 \mathrm{~min}$ retained considerable infectivity when bioassayed by permanent insertion into reporter mice (Flechsig et al. 2001). Transient insertion of prion-contaminated wires into the brains of naïve mice for as little as 30 min was sufficient to transmit infection without significantly reducing the remaining infectivity on the wire (Flechsig et al. 2001). Subsequently, transient insertion of a wire contaminated with $263 \mathrm{~K}$ prions for as little as 5 min was shown to efficiently transmit prion disease (Yan et al. 2004).

To determine how readily prions were able to adhere to steel wires, we tested contamination by transient insertion into the brains, as well as the duration of incubation in brain homogenate, of terminally ill mice infected with the mouse-passaged sheep scrapie strain RML. Surprisingly, the shortest contact times tested$30-\mathrm{sec}$ insertion and 15-min incubation with $10 \%$ brain homogenate-showed that wire surfaces adsorbed a similar level of infectivity as with the longer contact times (Table 1). This

Table 1. Incubation periods in $\operatorname{Tg}(\mathrm{MoPrP}) 4053$ mice following permanent implantation of wires contaminated with RML prions for different durations

\begin{tabular}{|c|c|c|c|}
\hline $\begin{array}{l}\text { Contaminating } \\
\text { procedure }\end{array}$ & Time & $\begin{array}{l}\text { Incubation } \\
\text { period } \\
\left(_{\text {days })^{a}}\right.\end{array}$ & $n / n_{0}^{b}$ \\
\hline $\begin{array}{l}\text { Transient insertion of } \\
\text { wire in terminal } \\
\text { RML-infected brain }\end{array}$ & $\begin{array}{l}30 \mathrm{sec} \\
90 \mathrm{sec} \\
5 \mathrm{~min}\end{array}$ & $\begin{array}{l}78 \pm 2 \\
83 \pm 1 \\
84 \pm 4\end{array}$ & $\begin{array}{l}5 / 5 \\
4 / 4 \\
4 / 4\end{array}$ \\
\hline $\begin{array}{l}\text { Incubating wire in } \\
10 \% \text { RML brain } \\
\text { homogenate }\end{array}$ & $\begin{array}{r}15 \text { min } \\
1 \mathrm{~h} \\
4 \mathrm{~h} \\
16 \mathrm{~h}\end{array}$ & $\begin{array}{l}88 \pm 3 \\
89 \pm 2 \\
86 \pm 4 \\
82 \pm 4\end{array}$ & $\begin{array}{l}3 / 3 \\
4 / 4 \\
4 / 4 \\
4 / 4\end{array}$ \\
\hline
\end{tabular}

${ }^{\mathrm{a}}$ Data reported as mean \pm standard error of the mean.

${ }^{\mathrm{b}} n$, number of mice showing clinical signs of disease; $n_{0}$, number of mice inoculated. 
suggests that wires, and by inference stainless steel surgical instruments and meat-processing equipment, can be rapidly saturated with prion infectivity.

\section{Inactivation of Human PrP Prions}

Early inactivation studies on CJD prions were performed under the assumption that CJD represented a single disease. However, it is now understood that there are multiple well-defined human prion strains. Moreover, multiple prion strains are not uncommon within a single brain (Parchi et al. 2009). A polymorphism at residue 129 of human $(\mathrm{Hu}) \mathrm{PrP}$, encoding methionine $(\mathrm{M})$ or valine $(\mathrm{V})$, has an allele frequency in the general population of $\sim 0.6 / 0.4$. Although $\mathrm{MV}$ heterozygotes represent around half of the population, they account for only $10 \%$ of sporadic CJD (sCJD) cases (Parchi et al. 1999). Additionally, biochemical analysis of sCJD prions can be broadly classified into two groups (termed type 1 and type 2), depending on the size of the PKresistant fragment of PrP. These strain types also correlate strongly with genotype; of the six possible genotype/strain-type combinations, MM individuals with type 1 prions, termed MM1, account for $\sim 70 \%$ of sCJD cases (Parchi et al. 1999). The six sporadic strain types represent at least four biologically distinct strains (Bishop et al. 2010). The genetic human prion diseases, including fatal familial insomnia (FFI) and Gerstmann-Sträussler-Scheinker (GSS), represent additional unique strains.

The first CJD transmission studies were performed in primates (Gibbs et al. 1968), which proved impractical for multiple prion inactivation experiments. Using a guinea pig-passaged CJD isolate, infectivity was reduced $>1000$-fold with $\mathrm{NaOCl}$ at concentrations of $0.5 \%$ or above within $15 \mathrm{~min}$, whereas potassium permanganate and a range of detergents had lesser effects even up to $4 \mathrm{~h}$ (Brown et al. 1982). Treatment with $1 \mathrm{~N} \mathrm{NaOH}$ at room temperature for $1 \mathrm{~h}$ was also effective (Brown et al. 1984), as was steam autoclaving at $121^{\circ} \mathrm{C}$ or $132^{\circ} \mathrm{C}$ for $1 \mathrm{~h}$ (Brown et al. 1986). However, the results of these experiments must be interpreted with caution - all of these studies were performed with guinea pig prions, and the original CJD prion strain used is not known.

Transmission of an unusual human prion disease isolate, likely to represent GSS, to mice led to the Fukuoka-1 (FU-1) strain (Tateishi et al. 1979). The American Neurological Association published precautions for handling CJD tissues, recommending steam autoclaving for $1 \mathrm{~h}$ at $132^{\circ} \mathrm{C}$ or immersion in $1 \mathrm{~N} \mathrm{NaOH}$ for $1 \mathrm{~h}$ at room temperature as "fully effective" (Rosenberg et al. 1986). However, treating the FU-1 strain with $2 \mathrm{~N} \mathrm{NaOH}$ for $2 \mathrm{~h}$ reduced its infectivity but failed to fully inactivate it (Tateishi et al. 1988). Serial passage of the FU-1 strain in mice led to the M1000 strain, which was used in combination with the steel wire model to test various prion inactivation strategies (Lawson et al. 2007). Soaking in $\mathrm{NaOH}$ or autoclaving had limited impact against M1000 prions bound to stainless steel. Different enzymatic cleaner formulations were slightly more effective (but only at elevated temperatures), and enzymatic cleaner in combination with autoclaving was required to remove all detectible infectivity (Lawson et al. 2007).

To determine whether the FU-1/M1000 strain was representative of human prions, we performed transmission studies in a series of $\mathrm{Tg}$ mice either overexpressing mouse $\mathrm{PrP}$ ( $\mathrm{Tg}(\mathrm{MoPrP}) 4053$ [Carlson et al. 1994]) or lacking endogenous mouse PrP but expressing a chimeric mouse/human $\operatorname{PrP}(\mathrm{Tg}(\mathrm{Mo} /$ HuPrP) 1014/Prnp ${ }^{0 / 0}$ [Giles et al. 2010]) or human $\operatorname{PrP}\left(\mathrm{Tg}(\mathrm{HuPrP}) 2669 /\right.$ Prnp $^{0 / 0}$ [Berry et al. 2013]). $\operatorname{Tg}(\mathrm{MoPrP}) 4053$ and $\operatorname{Tg}(\mathrm{Mo} /$ HuPrP $) 1014 /$ Prnp $^{0 / 0}$ mice were susceptible to RML prions, whereas the $\operatorname{Tg}(\mathrm{Mo} / \mathrm{HuPrP}) 1014$ and $\mathrm{Tg}(\mathrm{HuPrP}) 2669 / \operatorname{Prnp}^{0 / 0}$ lines were susceptible to human sCJD(MM1) prions. For RML prions, $\operatorname{Tg}(\mathrm{MoPrP}) 4053$ mice had incubation periods around half those of $\mathrm{Tg}(\mathrm{Mo} /$ HuPrP) $1014 / \operatorname{Prnp}^{0 / 0}$ mice, likely because of a higher expression level and exact sequence match with the $\operatorname{Tg}(\mathrm{MoPrP}) 4053$ line. $\operatorname{Tg}(\mathrm{MoPrP}) 4053$ and $\operatorname{Tg}(\mathrm{Mo} / \mathrm{HuPrP}) 1014 /$ $\operatorname{Prnp}^{0 / 0}$ mice inoculated with RML prions from $\mathrm{ScN} 2 \mathrm{a}$ cells showed longer incubation periods than those inoculated with RML brain homogenate (Table 2), reflecting the lower 
K. Giles et al.

Table 2. Incubation periods of the Fukuoka-1 (FU-1) prion strain in transgenic mice

\begin{tabular}{|c|c|c|c|}
\hline Inoculum & Host & $\begin{array}{c}\text { Incubation } \\
\text { period (days) }\end{array}$ & $n / n_{0}{ }^{b}$ \\
\hline \multirow[t]{2}{*}{ RML brain homogenate } & $\operatorname{Tg}(\mathrm{MoPrP}) 4053$ & $51 \pm 3^{c}$ & $8 / 8$ \\
\hline & $\operatorname{Tg}(\mathrm{Mo} / \mathrm{HuPrP}) 1014 / \operatorname{Prn}^{0 / 0}$ & $107 \pm 5^{c}$ & $4 / 4$ \\
\hline \multirow[t]{2}{*}{ CJD brain homogenate } & $\operatorname{Tg}(\mathrm{Mo} / \mathrm{HuPrP}) 1014 /$ Prnp $^{0 / 0}$ & $78 \pm 1^{\mathrm{c}}$ & $7 / 7$ \\
\hline & $\operatorname{Tg}(\mathrm{HuPrP}) 2669 / \operatorname{Prnp}^{0 / 0}$ & $143 \pm 2^{c}$ & $9 / 9$ \\
\hline \multirow[t]{2}{*}{ RML/N2a cell lysate } & $\operatorname{Tg}(\mathrm{MoPrP}) 4053$ & $77 \pm 3$ & $8 / 8$ \\
\hline & $\operatorname{Tg}(\mathrm{Mo} / \mathrm{HuPrP}) 1014 / \operatorname{Prn}^{0 / 0}$ & $154 \pm 1$ & $8 / 8$ \\
\hline \multirow[t]{3}{*}{ FU-1/N2a cell lysate } & $\operatorname{Tg}(\mathrm{MoPrP}) 4053$ & $103 \pm 2$ & $8 / 8$ \\
\hline & $\operatorname{Tg}(\mathrm{Mo} / \mathrm{HuPrP}) 1014 / \operatorname{Prn}^{0 / 0}$ & $103 \pm 4$ & $8 / 8$ \\
\hline & $\operatorname{Tg}(\mathrm{HuPrP}) 2669 / \operatorname{Prn}^{0 / 0}$ & $>500$ & $0 / 8$ \\
\hline FU-1/N2a cell lysate $\rightarrow$ & $\operatorname{Tg}(\mathrm{MoPrP}) 4053$ & $76 \pm 0$ & $8 / 8$ \\
\hline \multirow[t]{2}{*}{$\operatorname{Tg}(\mathrm{MoPrP}) 4053$} & $\operatorname{Tg}(\mathrm{Mo} / \mathrm{HuPrP}) 1014 / \operatorname{Prn}^{0 / 0}$ & $82 \pm 2$ & $7 / 7$ \\
\hline & $\operatorname{Tg}(\mathrm{HuPrP}) 2669 / \operatorname{Prn}^{0 / 0}$ & $>500$ & $0 / 6$ \\
\hline FU-1/N2a cell lysate $\rightarrow$ & $\operatorname{Tg}(\mathrm{MoPrP}) 4053$ & $120 \pm 10$ & $8 / 8$ \\
\hline \multirow[t]{2}{*}{$\mathrm{Tg}(\mathrm{Mo} / \mathrm{HuPrP}) 1014$} & $\operatorname{Tg}(\mathrm{Mo} / \mathrm{HuPrP}) 1014 / \operatorname{Prn}^{0 / 0}$ & $95 \pm 2$ & $8 / 8$ \\
\hline & $\operatorname{Tg}(\mathrm{HuPrP}) 2669 / \operatorname{Prnp}^{0 / 0}$ & $>500$ & $0 / 6$ \\
\hline
\end{tabular}

titer inoculated for the former. Interestingly, the FU-1 strain passaged in N2a cells had similar incubation periods in $\operatorname{Tg}(\operatorname{MoPrP}) 4053$ and $\mathrm{Tg}(\mathrm{Mo} / \mathrm{HuPrP}) 1014 / \operatorname{Prnp}^{0 / 0}$ mice, which were between the values for each line with RML-infected N2a cells. However, FU-1 prions failed to infect $\operatorname{Tg}(\mathrm{HuPrP}) 2669 / \operatorname{Prnp}^{0 / 0}$ mice (Table 2). FU-1 prions serially passaged in $\operatorname{Tg}(\mathrm{MoPrP}) 4053$ mice resulted in shorter subsequent incubation periods in $\operatorname{Tg}(\mathrm{MoPrP}) 4053$ and $\operatorname{Tg}(\mathrm{Mo} / \mathrm{HuPrP}) 1014 / \operatorname{Prn}^{0 / 0}$ mice, reflecting the higher titer of the brain homogenate inoculum compared with FU-1 infected N2a cells. However, following serial passage in $\mathrm{Tg}(\mathrm{Mo} / \mathrm{HuPrP}) 1014 / \operatorname{Prnp}^{0 / 0}$ mice, FU-1 prions had shorter incubation periods in $\mathrm{Tg}(\mathrm{Mo} /$ $\mathrm{HuPrP}) 1014 / \operatorname{Prnp}^{0 / 0}$ mice, but longer incubation periods in $\operatorname{Tg}(\mathrm{MoPrP}) 4053$ mice than the original FU-1 transmission, suggesting further adaptation of the strain in the $\operatorname{Tg}(\mathrm{Mo} /$ HuPrP) $1014 / \operatorname{Prnp}^{0 / 0}$ host. Neither of the serially passaged samples were able to infect $\mathrm{Tg}(\mathrm{HuPrP}) 2669 / \operatorname{Prnp}^{0 / 0}$ mice (Table 2). Although the FU-1 strain of mouse-passaged prions exhibits unusual transmission properties, it does not have the infectivity characteristics of common CJD strains; therefore its utility as a general model system for human prions is questionable.

\section{Direct Assay of Human PrP Prions}

To measure infectivity of CJD prions following various prion inactivation procedures, we used an alternate chimeric human/mouse $\mathrm{PrP} \mathrm{Tg}$ line, termed $\mathrm{Tg}(\mathrm{Mo} / \mathrm{HuPrP}) 22372 / \operatorname{Prnp}^{0 / 0}$ (Korth et al. 2003). Inoculation of serially diluted $\mathrm{sCJD}(\mathrm{MM} 1)$ prions into $\mathrm{Tg}(\mathrm{Mo} /$ HuPrP) $22372 / \operatorname{Prnp}^{0 / 0}$ mice showed that infectivity could still be detected in a $10^{-8}$ dilution of $10 \%$ brain homogenate (Peretz et al. 2006). From these data, we derived a Cox model to quantify inactivation procedures. We determined that although exposure of Sc237 prions to $2 \% \mathrm{SDS}-1 \% \mathrm{AcOH}$ at $65^{\circ} \mathrm{C}$ for $30 \mathrm{~min}$ produced a $9.0 \log _{10}$ reduction in titer, the same treatment on $\mathrm{sCJD}(\mathrm{MM} 1)$ prions yielded only a $3.8 \log _{10}$ reduction (Peretz et al. 2006). Thus, the sCJD prions were $>100,000$-fold more difficult to inactivate than Sc237 prions, an alarming conclusion for inactivation procedures touted as effective for health care settings but validated against the Sc237/263K prion strain. Extended incubation ( $18 \mathrm{~h}$ ) with $4 \%$ SDS-1\% 
$\mathrm{AcOH}$ at $65^{\circ} \mathrm{C}$ did remove all detectable $\mathrm{CJD}$ infectivity, as did $2 \%$ or $4 \%$ SDS with $1 \% \mathrm{AcOH}$ in combination with autoclaving (Peretz et al. 2006).

Similar to other prion strains, human sCJD prions bound to a stainless steel surface were more difficult to inactivate than those in solution. The majority of $\mathrm{Tg}(\mathrm{Mo} / \mathrm{HuPrP}) 22372 /$ $\operatorname{Prnp}^{0 / 0}$ mice implanted with sCJD-contaminated steel wires that had been subjected to $4 \% \mathrm{SDS}-1 \% \mathrm{AcOH}$ at $65^{\circ} \mathrm{C}$ for $18 \mathrm{~h}$ still developed clinical signs of prion disease. Only autoclaving in acidic SDS removed all detectable infectivity (Peretz et al. 2006). However, it should be noted that the sensitivity of the $\mathrm{Tg}(\mathrm{Mo} /$ HuPrP)22372/Prnp ${ }^{0 / 0}$ model for sCJD prions is at least 100-fold less than that used for Sc237 prions; therefore, low levels of infectivity could still be present.

\section{Alternatives to Animal Bioassays}

The complete removal of protein would by definition mean the complete removal of infectivity. Using an advanced light microscopy technique-episcopic differential interference contrast microscopy-and fluorescent amyloid-binding reagents, levels estimated to be $<100 \mathrm{fg}$ of protein were detected on the surface of surgical instruments (Lipscomb et al. 2007). This technique was also able to demonstrate the limitations of the "wire" model for prion infection, showing that prion-contaminated wires could be cleaned more easily than flat metal surfaces, which are more representative of surgical instruments (Lipscomb et al. 2006).

The QuIC assay was used to measure residual $\operatorname{PrP}$ seeding ability following treatments with $\mathrm{NaOH}$ and the commercial disinfectants Environ $\mathrm{LpH}$ and $\mathrm{BrioHOCl}$ on various prion strains (Hughson et al. 2016). Although this represents an advantage in terms of throughput, it was noted that elimination of prion infectivity is not always accompanied by loss of QuIC seeding activity (Hughson et al. 2016). In addition, the QuIC assay was modified to measure residual seeding from prion-contaminated wires (Hughson et al. 2016; Mori et al. 2016). Reducing the seeding ability of hamster prions on wires was compared with their infectivity by bioassay (Hughson et al. 2016), although, as noted above, the utility of this strain for prion inactivation studies relevant to CJD prions is limited (Peretz et al. 2006). The application of the QuIC methodology to wires contaminated with human CJD prions (Mori et al. 2016) may prove promising; however, as the authors note, the relationship between QuIC seeding and infectivity of human prions remains to be determined.

\section{Inactivation of Non-PrP Prions}

To date, $>95 \%$ of cases of iatrogenic CJD resulted from treatment of persons of short stature with growth hormone produced from pools of cadaver-derived pituitary glands or use of cadaver-derived dura mater grafts during neurosurgery. With the growing understanding that most, if not all, neurodegenerative diseases are caused by different proteins adopting self-propagating, or prion, conformations (Prusiner 2012), questions have arisen whether these too could be spread iatrogenically.

Reanalysis of the brains from patients who received growth hormone and developed iatrogenic CJD showed that a number of them also contained $A \beta$ pathology that was not present in age-matched controls (Jaunmuktane et al. 2015). This suggests that $A \beta$ seeds from the original pituitary glands had also induced an iatrogenic $\mathrm{A} \beta$ amyloidosis. Similar observations were made in iatrogenic CJD patients who received dura mater grafts (Frontzek et al. 2016; Kovacs et al. 2016). Tau pathology was not observed in any of these cases.

In the Tg mouse model, $A \beta$ seeding activity was completely inactivated by $70 \%$ formic acid for $1 \mathrm{~h}$ and reduced after incubating at $95^{\circ} \mathrm{C}$ for 5 min (Meyer-Luehmann et al. 2006). In an analogous experiment to PrP prion studies, stainless steel wires were incubated in brain homogenate from aged TgAPP 23 mice. Wires contaminated with $A \beta$ prions were able to seed $A \beta$-amyloidosis in the brains of young TgAPP23 mice (Eisele et al. 2009). Heating $A \beta$-contaminated wires in PBS to $95^{\circ} \mathrm{C}$ for $10 \mathrm{~min}$ did not diminish amyloid-seeding ability. However, after ex- 
K. Giles et al.

posing $A \beta$-contaminated wires to hydrogen peroxide plasma sterilization (Sterrad S100, long cycle), they did not seed $A \beta$-amyloidosis (Eisele et al. 2009). Interestingly, the same plasma sterilization procedure had minimal impact on stainless steel wires contaminated with the 263K PrP prion strain (Rogez-Kreuz et al. 2009).

$\mathrm{AD}$ patient brain extracts that had been fixed in formaldehyde for $2 \mathrm{yr}$ induced a robust $A \beta$ amyloidosis when inoculated intracerebrally into TgAPP23 mice (Fritschi et al. 2014). Brains from two TgAPP mouse models were either fixed in formaldehyde or flash frozen and were shown to seed both in vitro and in vivo, with the fixation process only moderately lowering the $\mathrm{A} \beta$ prion titer (Fritschi et al. 2014). The resistance of $A \beta$ aggregates to degradation in vivo was demonstrated by inoculation of mice lacking endogenous APP with brain homogenate from aged TgAPP 23 mice. Brains taken from these mice up to 6 mo after inoculation were still able to seed $A \beta$ amyloidosis in reporter mice (Ye et al. 2015).

As with $\mathrm{PrP}$ and $\mathrm{A} \beta$ prions, the infectivity of $\alpha$-synuclein prions is only slightly reduced by formalin fixation. In the A30P Tg model, inoculation of formalin fixed tissue from an aged mouse greatly accelerated disease onset in young mice of the same strain (Schweighauser et al. 2015). $\alpha$-Synuclein prion inactivation procedures published to date have only been reported to reduce protein level and have not been validated in vivo. Measuring residual protein removed from stainless steel grids contaminated with $\alpha$-synuclein prions demonstrated that harsh alkaline treatments, including $1 \mathrm{M}$ $\mathrm{NaOH}$ for $1 \mathrm{~h}$ or $0.2 \%$ SDS $-0.3 \% \mathrm{NaOH}$, reduced recoverable protein loads by $>100$-fold (Thomzig et al. 2014). A more comprehensive study using plastic, glass, aluminum, and stainless steel plates spotted with synthetic $\alpha$ synuclein aggregates quantified the remaining aggregates by binding of a fluorescent dye. Interestingly, $\mathrm{NaOH}$ and $\mathrm{NaOCl}$ were among the least effective in reducing $\alpha$-synuclein, especially on plastic and glass surfaces, potentially exacerbating the inactivation problem by denaturing protein on the surface rather than solubilizing it (Bousset et al. 2016).
Immunoblotting and QuIC were used to test the effect of $\mathrm{BioHOCl}$ on aggregated recombinant $\alpha$-synuclein and Lewy body isolates from DLB patients. Longer treatments and more concentrated $\mathrm{BioHOCl}$ were required for the brain extracts than for the synthetic fibrils (Hughson et al. 2016). Reduced seeding was also observed after BioHOCl treatment of aggregated tau peptide, increasing the lag phase by the equivalent of a 1000-fold dilution of seed (Hughson et al. 2016).

\section{CONCLUSIONS}

Prions are proteins that transmit infectivity by templating their conformation onto copies of the same protein. It is therefore not surprising that conditions required to inactivate them differ from the disinfection of nucleic acid-based replicators such as bacteria and viruses. Differences in protein sequence between species also impact the efficacy of prion inactivation, such that rodent-passaged PrP prions do not necessarily predict efficacy against the natural strain from which they are derived.

With the growing incidence of neurodegenerative diseases among the aging population, it will be increasingly important to closely monitor procedures that could result in iatrogenic transmission of disease and to develop prion inactivation methods that are rigorously validated against all relevant prion strains.

\section{ACKNOWLEDGMENTS}

The authors acknowledge support from the $\mathrm{Na}$ tional Institutes of Health (AG002132 and AG031220), Daiichi Sankyo, Henry M. Jackson Foundation, Glenn Foundation, Mary Jane Brinton Fund, Sherman Fairchild Foundation, and a gift from the Rainwater Charitable Foundation.

\section{REFERENCES}

Alper T, Cramp WA, Haig DA, Clarke MC. 1967. Does the agent of scrapie replicate without nucleic acid? Nature 214: $764-766$. 
Alper T, Haig DA, Clarke MC. 1966. The exceptionally small size of the scrapie agent. Biochem Biophys Res Commun 22: $278-284$.

Atarashi R, Wilham JM, Christensen L, Hughson AG, Moore RA, Johnson LM, Onwubiko HA, Priola SA, Caughey B. 2008. Simplified ultrasensitive prion detection by recombinant PrP conversion with shaking. Nat Methods 5: 211-212.

Baker HF, Ridley RM, Duchen LW, Crow TJ, Bruton CJ. 1994. Induction of $B(A 4)$-amyloid in primates by injection of Alzheimer's disease brain homogenate. $\mathrm{Mol} \mathrm{Neu-}$ robiol 8: 25-39.

Berry DB, Lu D, Geva M, Watts JC, Bhardwaj S, Oehler A, Renslo AR, DeArmond SJ, Prusiner SB, Giles K. 2013. Drug resistance confounding prion therapeutics. Proc Natl Acad Sci 110: E4160-E4169.

Bishop MT, Will RG, Manson JC. 2010. Defining sporadic Creutzfeldt-Jakob disease strains and their transmission properties. Proc Natl Acad Sci 107: 12005-12010.

Bosque PJ, Prusiner SB. 2000. Cultured cell sublines highly susceptible to prion infection. J Virol 74: 4377-4386.

Bousset L, Brundin P, Böckmann A, Meier B, Melki R. 2016. An efficient procedure for removal and inactivation of $\alpha$ synuclein assemblies from laboratory materials. J Parkinsons Dis 6: 143-151.

Brown P, Gibbs CJ Jr, Amyx HL, Kingsbury DT, Rohwer RG, Sulima MP, Gajdusek DC. 1982. Chemical disinfection of Creutzfeldt-Jakob disease virus. $N$ Engl J Med 306: 1279-1282.

Brown P, Rohwer RG, Gajdusek DC. 1984. Sodium hydroxide decontamination of Creutzfeldt-Jakob disease virus. N Engl J Med 310: 727.

Brown P, Rohwer RG, Gajdusek DC. 1986. Newer data on the inactivation of scrapie virus or Creutzfeldt-Jakob disease virus in brain tissue. J Infect Dis 153: 1145-1148.

Brown SA, Merritt K, Woods TO, Busick DN. 2005. Effects on instruments of the World Health Organization-recommended protocols for decontamination after possible exposure to transmissible spongiform encephalopathycontaminated tissue. J Biomed Mater Res B Appl Biomater 72: $186-190$.

Büeler H, Aguzzi A, Sailer A, Greiner RA, Autenried P, Aguet M, Weissmann C. 1993. Mice devoid of PrP are resistant to scrapie. Cell 73: 1339-1347.

Butler DA, Scott MR, Bockman JM, Borchelt DR, Taraboulos A, Hsiao KK, Kingsbury DT, Prusiner SB. 1988. Scrapie-infected murine neuroblastoma cells produce protease-resistant prion proteins. J Virol 62: 1558-1564.

Carlson GA, Ebeling C, Yang SL, Telling G, Torchia M, Groth D, Westaway D, DeArmond SJ, Prusiner SB. 1994. Prion isolate specified allotypic interactions between the cellular and scrapie prion proteins in congenic and transgenic mice. Proc Natl Acad Sci 91: 5690-5694.

Castilla J, Saá P, Hetz C, Soto C. 2005. In vitro generation of infectious scrapie prions. Cell 121: 195-206.

Chandler RL. 1961. Encephalopathy in mice produced by inoculation with scrapie brain material. Lancet 277: $1378-1379$.

Chandler RL. 1962. Encephalopathy in mice. Lancet 279: $107-108$.
Clavaguera F, Bolmont T, Crowther RA, Abramowski D, Frank S, Probst A, Fraser G, Stalder AK, Beibel M, Staufenbiel M, et al. 2009. Transmission and spreading of tauopathy in transgenic mouse brain. Nat Cell Biol 11: 909-913.

Clavaguera F, Akatsu H, Fraser G, Crowther RA, Frank S, Hench J, Probst A, Winkler DT, Reichwald J, Staufenbiel M, et al. 2013. Brain homogenates from human tauopathies induce tau inclusions in mouse brain. Proc Natl Acad Sci 110: 9535-9540.

Clavaguera F, Tolnay M, Goedert M. 2016. The prionlike behavior of assembled tau in transgenic mice. Cold Spring Harb Perspect Med doi: 10.1101/cshperspect .a024372.

Colby DW, Zhang Q, Wang S, Groth D, Legname G, Riesner D, Prusiner SB. 2007. Prion detection by an amyloid seeding assay. Proc Natl Acad Sci 104: 20914-20919.

Cuillé J, Chelle PL. 1936. La maladie dite tremblante du mouton est-elle inoculable? C R Acad Sci 203: 15521554.

Cuillé J, Chelle PL. 1939. Transmission experimentale de la tremblante a la chevre. C R Acad Sci 208: 1058-1060.

Dickinson AG, Taylor DM. 1978. Resistance of scrapie agent to decontamination. $N$ Engl J Med 299: 1413-1414.

Eisele YS, Bolmont T, Heikenwalder M, Langer F, Jacobson LH, Yan ZX, Roth K, Aguzzi A, Staufenbiel M, Walker LC, et al. 2009. Induction of cerebral $\beta$-amyloidosis: Intracerebral versus systemic A $\beta$ inoculation. Proc Natl Acad Sci 106: 12926-12931.

Eklund CM, Hadlow WJ, Kennedy RC. 1963. Some properties of the scrapie agent and its behavior in mice. Proc Soc Exp Biol Med 112: 974-979.

Fairfoul G, McGuire LI, Pal S, Ironside JW, Neumann J, Christie S, Joachim C, Esiri M, Evetts SG, Rolinski M, et al. 2016. $\alpha$-Synuclein RT-QuIC in the CSF of patients with $\alpha$-synucleinopathies. Ann Clin Transl Neurol 3: 812-818.

Fichet G, Comoy E, Duval C, Antloga K, Dehen C, Charbonnier A, McDonnell G, Brown P, Lasmézas CI, Deslys JP. 2004. Novel methods for disinfection of prion-contaminated medical devices. Lancet 364: 521-526.

Flechsig E, Hegyi I, Enari M, Schwarz P, Collinge J, Weissmann C. 2001. Transmission of scrapie by steel-surfacebound prions. Mol Med 7: 679-684.

Fritschi SK, Cintron A, Ye L, Mahler J, Bühler A, Baumann F, Neumann M, Nilsson KPR, Hammarström P, Walker LC, et al. 2014. A $\beta$ seeds resist inactivation by formaldehyde. Acta Neuropathol 128: 477-484.

Frontzek K, Lutz MI, Aguzzi A, Kovacs GG, Budka H. 2016. Amyloid- $\beta$ pathology and cerebral amyloid angiopathy are frequent in iatrogenic Creutzfeldt-Jakob disease after dural grafting. Swiss Med Wkly 146: w14287.

Gajdusek DC, Gibbs CJ Jr, Alpers M. 1966. Experimental transmission of a kuru-like syndrome to chimpanzees. Nature 209: 794-796.

Giasson BI, Duda JE, Quinn SM, Zhang B, Trojanowski JQ, Lee VM. 2002. Neuronal $\alpha$-synucleinopathy with severe movement disorder in mice expressing A53T human $\alpha$ synuclein. Neuron 34: 521-533.

Gibbs CJ Jr, Gajdusek DC, Asher DM, Alpers MP, Beck E, Daniel PM, Matthews WB. 1968. Creutzfeldt-Jakob dis- 
K. Giles et al.

ease (spongiform encephalopathy): Transmission to the chimpanzee. Science 161: 388-389.

Giles K, Glidden DV, Beckwith R, Seoanes R, Peretz D, DeArmond SJ, Prusiner SB. 2008. Resistance of bovine spongiform encephalopathy (BSE) prions to inactivation. PLoS Pathog 4: e1000206.

Giles K, Glidden DV, Patel S, Korth C, Groth D, Lemus A, DeArmond SJ, Prusiner SB. 2010. Human prion strain selection in transgenic mice. Ann Neurol 68: 151-161.

Gordon WS. 1946. Advances in veterinary research. Vet Rec 58: $516-520$.

Hasegawa M, Nonaka T, Masuda-Suzukake M. 2016. $\alpha$-Synuclein: Experimental pathology. Cold Spring Harb Perspect Med 6: a024273.

Holmes BB, Diamond MI. 2017. Cellular models for the study of prions. Cold Spring Harb Perspect Med 7: a024026.

Hughson AG, Race B, Kraus A, Sangaré LR, Robins L, Groveman BR, Saijo E, Phillips K, Contreras L, Dhaliwal V, et al. 2016. Inactivation of prions and amyloid seeds with hypochlorous acid. PLoS Pathog 12: e1005914.

Hunter GD, Millson GC, Chandler RL. 1963. Observations on the comparative infectivity of cellular fractions derived from homogenates of mouse-scrapie brain. Res Vet Sci 4: 543-549.

Iba M, Guo JL, McBride JD, Zhang B, Trojanowski JQ, Lee VM. 2013. Synthetic tau fibrils mediate transmission of neurofibrillary tangles in a transgenic mouse model of Alzheimer's-like tauopathy. J Neurosci 33: 1024-1037.

Jaunmuktane Z, Mead S, Ellis M, Wadsworth JD, Nicoll AJ, Kenny J, Launchbury F, Linehan J, Richard-Loendt A, Walker AS, et al. 2015. Evidence for human transmission of amyloid- $\beta$ pathology and cerebral amyloid angiopathy. Nature 525: 247-250.

Kane MD, Lipinski WJ, Callahan MJ, Bian F, Durham RA, Schwarz RD, Roher AE, Walker LC. 2000. Evidence for seeding of $\beta$-amyloid by intracerebral infusion of Alzheimer brain extracts in $\beta$-amyloid precursor proteintransgenic mice. J Neurosci 20: 3606-3611.

Kimberlin R, Walker C. 1977. Characteristics of a short incubation model of scrapie in the golden hamster. J Gen Virol 34: 295-304.

Kocisko DA, Come JH, Priola SA, Chesebro B, Raymond GJ, Lansbury PT Jr, Caughey B. 1994. Cell-free formation of protease-resistant prion protein. Nature 370: 471-474.

Kocisko DA, Priola SA, Raymond GJ, Chesebro B, Lansbury PT Jr, Caughey B. 1995. Species specificity in the cell-free conversion of prion protein to protease-resistant forms: A model for the scrapie species barrier. Proc Natl Acad Sci 92: 3923-3927.

Korth C, Kaneko K, Groth D, Heye N, Telling G, Mastrianni J, Parchi P, Gambetti P, Will R, Ironside J, et al. 2003. Abbreviated incubation times for human prions in mice expressing a chimeric mouse-human prion protein transgene. Proc Natl Acad Sci 100: 4784-4789.

Kovacs GG, Lutz MI, Ricken G, Ströbel T, Höftberger R, Preusser M, Regelsberger G, Hönigschnabl S, Reiner A, Fischer P, et al. 2016. Dura mater is a potential source of A $\beta$ seeds. Acta Neuropathol 131: 911-923.

Lasagna-Reeves CA, Castillo-Carranza DL, Sengupta U, Guerrero-Munoz MJ, Kiritoshi T, Neugebauer V, Jackson GR, Kayed R. 2012. Alzheimer brain-derived tau oligo- mers propagate pathology from endogenous tau. Sci Rep 2: 700.

Lawson VA, Stewart JD, Masters CL. 2007. Enzymatic detergent treatment protocol that reduces protease-resistant prion protein load and infectivity from surgical-steel monofilaments contaminated with a human-derived prion strain. J Gen Virol 88: 2905-2914.

Lipscomb IP, Pinchin HE, Collin R, Harris K, Keevil CW. 2006. Are surgical stainless steel wires used for intracranial implantation of $\mathrm{PrP}^{\mathrm{Sc}}$ a good model of iatrogenic transmission from contaminated surgical stainless steel instruments after cleaning? J Hosp Infect 64: 339-343.

Lipscomb IP, Hervé R, Harris K, Pinchin H, Collin R, Keevil CW. 2007. Amyloid-specific fluorophores for the rapid, sensitive in situ detection of prion contamination on surgical instruments. J Gen Virol 88: 2619-2626.

Luk KC, Kehm V, Carroll J, Zhang B, O'Brien P, Trojanowski JQ, Lee VM. 2012a. Pathological $\alpha$-synuclein transmission initiates Parkinson-like neurodegeneration in nontransgenic mice. Science 338: 949-953.

Luk KC, Kehm VM, Zhang B, O’Brien P, Trojanowski JQ, Lee VM. 2012b. Intracerebral inoculation of pathological $\alpha$ synuclein initiates a rapidly progressive neurodegenerative $\alpha$-synucleinopathy in mice. J Exp Med 209: 975-986.

Mahal SP, Baker CA, Demczyk CA, Smith EW, Julius C, Weissmann C. 2007. Prion strain discrimination in cell culture: The cell panel assay. Proc Natl Acad Sci 104: 20908-20913.

McKinley MP, Masiarz FR, Prusiner SB. 1981. Chemical modification of a scrapie agent protein by diethylpyrocarbonate. Trans Am Neurol Assoc 106: 293-296.

McKinley MP, Bolton DC, Prusiner SB. 1983. A proteaseresistant protein is a structural component of the scrapie prion. Cell 35: 57-62.

Meyer-Luehmann M, Coomaraswamy J, Bolmont T, Kaeser S, Schaefer C, Kilger E, Neuenschwander A, Abramowski D, Frey P, Jaton AL, et al. 2006. Exogenous induction of cerebral $\beta$-amyloidogenesis is governed by agent and host. Science 313: 1781-1784.

Mori T, Atarashi R, Furukawa K, Takatsuki H, Satoh K, Sano K, Nakagaki T, Ishibashi D, Ichimiya K, Hamada M, et al. 2016. A direct assessment of human prion adhered to steel wire using real-time quaking-induced conversion. Sci Rep 6: 24993.

Mougenot AL, Nicot S, Bencsik A, Morignat E, Verchère J, Lakhdar L, Legastelois S, Baron T. 2012. Prion-like acceleration of a synucleinopathy in a transgenic mouse model. Neurobiol Aging 33: 2225-2228.

Nishida N, Harris DA, Vilette D, Laude H, Frobert Y, Grassi J, Casanova D, Milhavet O, Lehmann S. 2000. Successful transmission of three mouse-adapted scrapie strains to murine neuroblastoma cell lines overexpressing wildtype mouse prion protein. J Virol 74: 320-325.

Parchi P, Giese A, Capellari S, Brown P, Schulz-Schaeffer W, Windl O, Zerr I, Budka H, Kopp N, Piccardo P, et al. 1999. Classification of sporadic Creutzfeldt-Jakob disease based on molecular and phenotypic analysis of 300 subjects. Ann Neurol 46: 224-233.

Parchi P, Strammiello R, Notari S, Giese A, Langeveld JP, Ladogana A, Zerr I, Roncaroli F, Cras P, Ghetti B, et al. 2009. Incidence and spectrum of sporadic CreutzfeldtJakob disease variants with mixed phenotype and co- 
occurrence of $\operatorname{PrP}^{\mathrm{Sc}}$ types: An updated classification. Acta Neuropathol 118: 659-671.

Pattison IH. 1966. The relative susceptibility of sheep, goats and mice to two types of the goat scrapie agent. Res Vet Sci 7: 207-212.

Pattison IH, Millson GC. 1960. Further observations on the experimental production of scrapie in goats and sheep. J Comp Pathol 70: 182-193.

Pattison IH, Millson GC. 1961. Scrapie produced experimentally in goats with special reference to the clinical syndrome. J Comp Pathol 71: 101-108.

Peretz D, Supattapone S, Giles K, Vergara J, Freyman Y, Lessard P, Safar JG, Glidden DV, McCulloch C, Nguyen $\mathrm{HO}$, et al. 2006. Inactivation of prions by acidic sodium dodecyl sulfate. J Virol 80: 322-331.

Poisson M, Magdelenat H, Foncin JF, Bleibel JM, Philippon J, Pertuiset B, Buge A. 1980. Récepteurs d'cestrogénes et de progestérone dans les méningiomes. Rev Neurol ( $\mathrm{Pa}-$ ris) 136: 193-203.

Probst A, Gotz J, Wiederhold KH, Tolnay M, Mistl C, Jaton AL, Hong M, Ishihara T, Lee VM, Trojanowski JQ, et al. 2000. Axonopathy and amyotrophy in mice transgenic for human four-repeat tau protein. Acta Neuropathol 99: $469-481$.

Prusiner SB. 2012. A unifying role for prions in neurodegenerative diseases. Science 336: 1511-1513.

Prusiner SB, Groth DF, Cochran SP, Masiarz FR, McKinley MP, Martinez HM. 1980. Molecular properties, partial purification, and assay by incubation period measurements of the hamster scrapie agent. Biochemistry 21: 4883-4891.

Prusiner SB, Groth DF, McKinley MP, Cochran SP, Bowman KA, Kasper KC. 1981a. Thiocyanate and hydroxyl ions inactivate the scrapie agent. Proc Natl Acad Sci 78: 46064610.

Prusiner SB, McKinley MP, Groth DF, Bowman KA, Mock NI, Cochran SP, Masiarz FR. 1981b. Scrapie agent contains a hydrophobic protein. Proc Natl Acad Sci 78: 66756679.

Prusiner SB, Cochran SP, Groth DF, Downey DE, Bowman KA, Martinez HM. 1982. Measurement of the scrapie agent using an incubation time interval assay. Ann Neurol 11: $353-358$.

Prusiner SB, McKinley MP, Bolton DC, Bowman KA, Groth DF, Cochran SP, Hennessey EM, Braunfeld MB, Baringer JR, Chatigny MA. 1984. Prions: Methods for assay, purification and characterization. In Methods in virology (ed. Maramorosch K, Koprowski H), pp. 293-345. Academic, New York.

Prusiner SB, Scott M, Foster D, Pan KM, Groth D, Mirenda C, Torchia M, Yang SL, Serban D, Carlson GA, et al. 1990. Transgenetic studies implicate interactions between homologous PrP isoforms in scrapie prion replication. Cell 63: $673-686$.

Prusiner SB, Woerman AL, Rampersaud R, Watts JC, Berry DB, Patel S, Oehler A, Lowe JK, Kravitz SN, Geschwind $\mathrm{DH}$, et al. 2015. Evidence for $\alpha$-synuclein prions causing multiple system atrophy in humans with signs of Parkinson's disease. Proc Natl Acad Sci 112: E5308-E5317.
Race RE, Fadness LH, Chesebro B. 1987. Characterization of scrapie infection in mouse neuroblastoma cells. J Gen Virol 68: 1391-1399.

Recasens A, Dehay B, Bové J, Carballo-Carbajal I, Dovero S, Pérez-Villalba A, Fernagut PO, Blesa J, Parent A, Perier C, et al. 2014. Lewy body extracts from Parkinson's disease brains trigger $\alpha$-synuclein pathology and neurodegeneration in mice and monkeys. Ann Neurol 75: 351-362.

Ridley RM, Baker HF, Windle CP, Cummings RM. 2006. Very long term studies of the seeding of $\beta$-amyloidosis in primates. J Neural Transm 113: 1243-1251.

Rogez-Kreuz C, Yousfi R, Soufflet C, Quadrio I, Yan ZX, Huyot V, Aubenque C, Destrez P, Roth K, Roberts C, et al. 2009. Inactivation of animal and human prions by hydrogen peroxide gas plasma sterilization. Infect Control Hosp Epidemiol 30: 769-777.

Rosenberg RN, White LL III, Brown P, Gajdusek DC, Volpe JJ, Posner J, Dyck PJ. 1986. Precautions in handling tissues, fluids, and other contaminated materials from patients with documented or suspected Creutfeldt-Jakob disease. Ann Neurol 19: 75-77.

Rubenstein R, Carp RI, Callahan SH. 1984. In vitro replication of scrapie agent in a neuronal model: Infection of PC12 cells. J Gen Virol 65: 2191-2198.

Rubenstein R, Deng H, Race RE, Ju W, Scalici CL, Papini MC, Kascsak R, Carp RI. 1992. Demonstration of scrapie strain diversity in infected PC12 cells. J Gen Virol 73: 3027-3031.

Saborio GP, Permanne B, Soto C. 2001. Sensitive detection of pathological prion protein by cyclic amplification of protein misfolding. Nature 411: 810-813.

Safar J, Wille H, Itri V, Groth D, Serban H, Torchia M, Cohen FE, Prusiner SB. 1998. Eight prion strains have $\operatorname{PrP}^{\mathrm{Sc}}$ molecules with different conformations. Nat Med 4: 1157-1165.

Safar JG, Geschwind MD, Deering C, Didorenko S, Sattavat M, Sanchez H, Serban A, Vey M, Baron H, Giles K, et al. 2005. Diagnosis of human prion disease. Proc Natl Acad Sci 102: 3501-3506.

Sanders DW, Kaufman SK, DeVos SL, Sharma AM, Mirbaha H, Li A, Barker SJ, Foley AC, Thorpe JR, Serpell LC, et al. 2014. Distinct tau prion strains propagate in cells and mice and define different tauopathies. Neuron 82: 1271-1288.

Schätzl HM, Laszlo L, Holtzman DM, Tatzelt J, DeArmond SJ, Weiner RI, Mobley WC, Prusiner SB. 1997. A hypothalamic neuronal cell line persistently infected with scrapie prions exhibits apoptosis. J Virol 71: 8821-8831.

Schweighauser M, Bacioglu M, Fritschi SK, Shimshek DR, Kahle PJ, Eisele YS, Jucker M. 2015. Formaldehyde-fixed brain tissue from spontaneously ill $\alpha$-synuclein transgenic mice induces fatal $\alpha$-synucleinopathy in transgenic hosts. Acta Neuropathol 129: 157-159.

Stamp JT, Brotherston JG, Zlotnik I, Mackay JMK, Smith W. 1959. Further studies on scrapie. J Comp Pathol 69: 268280.

Stöhr J, Watts JC, Mensinger ZL, Oehler A, Grillo SK, DeArmond SJ, Prusiner SB, Giles K. 2012. Purified and synthetic Alzheimer's amyloid $\beta(A \beta)$ prions. Proc Natl Acad Sci 109: 11025-11030. 
K. Giles et al.

Stöhr J, Condello C, Watts JC, Bloch L, Oehler A, Nick M, DeArmond SJ, Giles K, DeGrado WF, Prusiner SB. 2014. Distinct synthetic $A \beta$ prion strains producing different amyloid deposits in bigenic mice. Proc Natl Acad Sci 111: 10329-10334.

Supattapone S, Nguyen HO, Cohen FE, Prusiner SB, Scott MR. 1999. Elimination of prions by branched polyamines and implications for therapeutics. Proc Natl Acad Sci 96: 14529-14534.

Supattapone S, Wille H, Uyechi L, Safar J, Tremblay P, Szoka FC, Cohen FE, Prusiner SB, Scott MR. 2001. Branched polyamines cure prion-infected neuroblastoma cells. J Virol 75: 3453-3461.

Tamgüney G, Francis KP, Giles K, Lemus A, DeArmond SJ, Prusiner SB. 2009. Measuring prions by bioluminescence imaging. Proc Natl Acad Sci 106: 15002-15006.

Tateishi J, Ohta M, Koga M, Sato Y, Kuroiwa Y. 1979. Transmission of chronic spongiform encephalopathy with kuru plaques from humans to small rodents. Ann Neurol 5: $581-584$.

Tateishi J, Tashima T, Kitamoto T. 1988. Inactivation of the Creutzfeldt-Jakob disease agent. Ann Neurol 24: 466.

Taylor DM. 1999. Inactivation of prions by physical and chemical means. J Hosp Infect 43: S69-S76.

Telling GC, Scott M, Mastrianni J, Gabizon R, Torchia M, Cohen FE, DeArmond SJ, Prusiner SB. 1995. Prion propagation in mice expressing human and chimeric PrP transgenes implicates the interaction of cellular $\operatorname{PrP}$ with another protein. Cell 83: 79-90.

Thomzig A, Wagenführ K, Daus ML, Joncic M, SchulzSchaeffer WJ, Thanheiser M, Mielke M, Beekes M. 2014. Decontamination of medical devices from pathological amyloid- $\beta$-, tau- and $\alpha$-synuclein aggregates. Acta Neuropathol Commun 2: 151.

Vorberg I, Raines A, Story B, Priola SA. 2004. Susceptibility of common fibroblast cell lines to transmissible spongiform encephalopathy agents. J Infect Dis 189: 431-439.

Watts JC, Prusiner SB. 2014. Mouse models for studying the formation and propagation of prions. J Biol Chem 289: 19841-19849.

Watts JC, Prusiner SB. 2016. $\beta$-Amyloid prions and the pathobiology of Alzheimer's disease. Cold Spring Harb Perspect Med doi: 10.1101/cshperspect.a023507.

Watts JC, Giles K, Grillo SK, Lemus A, DeArmond SJ, Prusiner SB. 2011. Bioluminescence imaging of $A \beta$ deposi- tion in bigenic mouse models of Alzheimer's disease. Proc Natl Acad Sci 108: 2528-2533.

Watts JC, Giles K, Oehler A, Middleton L, Dexter DT, Gentleman SM, DeArmond SJ, Prusiner SB. 2013. Transmission of multiple system atrophy prions to transgenic mice. Proc Natl Acad Sci 110: 19555-19560.

Watts JC, Condello C, Stöhr J, Oehler A, Lee J, DeArmond SJ, Lannfelt L, Ingelsson M, Giles K, Prusiner SB. 2014. Serial propagation of distinct strains of $A \beta$ prions from Alzheimer's disease patients. Proc Natl Acad Sci 111: 10323-10328.

Wilesmith JW, Wells GA, Cranwell MP, Ryan JB. 1988. Bovine spongiform encephalopathy: Epidemiological studies. Vet Rec 123: 638-644.

Wilson DR, Anderson RD, Smith W. 1950. Studies in scrapie. J Comp Pathol 60: 267-282.

Woerman AL, Stöhr J, Aoyagi A, Rampersaud R, Krejciova Z, Watts JC, Ohyama T, Patel S, Widjaja K, Oehler A, et al. 2015. Propagation of prions causing synucleinopathies in cultured cells. Proc Natl Acad Sci 112: E4949-E4958.

Woerman AL, Watts JC, Aoyagi A, Giles K, Middleton LT, Prusiner SB. 2016. $\alpha$-Synuclein: Multiple system atrophy prions. Cold Spring Harb Perspect Med doi: 10.1101/ cshperspect.a024588.

World Health Organization. 1999. WHO infection control guidelines for transmissible spongiform encephalopathies. World Health Organization Emerging and Other Communicable Diseases. Geneva, Switzerland.

Yan ZX, Stitz L, Heeg P, Pfaff E, Roth K. 2004. Infectivity of prion protein bound to stainless steel wires: A model for testing decontamination procedures for transmissible spongiform encephalopathies. Infect Control Hosp Epidemiol 25: 280-283.

Ye L, Fritschi SK, Schelle J, Obermüller U, Degenhardt K, Kaeser SA, Eisele YS, Walker LC, Baumann F, Staufenbiel $\mathrm{M}$, et al. 2015. Persistence of A $\beta$ seeds in APP null mouse brain. Nat Neurosci 18: 1559-1561.

Yoshiyama Y, Higuchi M, Zhang B, Huang SM, Iwata N, Saido TC, Maeda J, Suhara T, Trojanowski JQ, Lee VM. 2007. Synapse loss and microglial activation precede tangles in a P301S tauopathy mouse model. Neuron 53: 337 351.

Zobeley E, Flechsig E, Cozzio A, Enari M, Weissmann C. 1999. Infectivity of scrapie prions bound to a stainless steel surface. Mol Med 5: 240-243. 


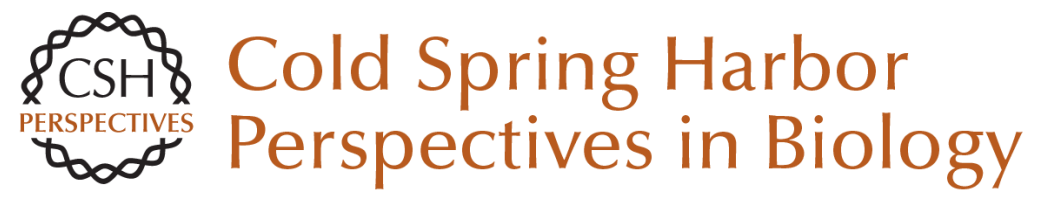

\section{Bioassays and Inactivation of Prions}

Kurt Giles, Amanda L. Woerman, David B. Berry and Stanley B. Prusiner

Cold Spring Harb Perspect Biol 2017; doi: 10.1101/cshperspect.a023499 originally published online February 28, 2017

\section{Subject Collection Prion Biology}

Genetic PrP Prion Diseases

Mee-Ohk Kim, Leonel T. Takada, Katherine Wong, et al.

Neurodegenerative Disease Transmission and Transgenesis in Mice Brittany N. Dugger, Daniel P. Perl and George A. Carlson

Toward the Atomic Structure of PrPSc Jose A. Rodriguez, Lin Jiang and David S. Eisenberg

Bioassays and Inactivation of Prions Kurt Giles, Amanda L. Woerman, David B. Berry, et al.

Functional Prions in the Brain Joseph B. Rayman and Eric R. Kandel

The Amyloid Phenomenon and Its Links with Human Disease Christopher M. Dobson

Tau Positron Emission Tomography Imaging Hartmuth C. Kolb and José Ignacio Andrés

Prion-Like Polymerization in Immunity and Inflammation

Xin Cai, Hui Xu and Zhijian J. Chen
Clinical Neurology and Epidemiology of the Major Neurodegenerative Diseases Michael G. Erkkinen, Mee-Ohk Kim and Michael D. Geschwind

Prion Properties of SOD1 in Amyotrophic Lateral Sclerosis and Potential Therapy Caroline Sibilla and Anne Bertolotti

Mapping Neurodegenerative Disease Onset and Progression William W. Seeley

Erratum: Functional Prions in the Brain Joseph B. Rayman and Eric R. Kandel

Pathology of Neurodegenerative Diseases Brittany N. Dugger and Dennis W. Dickson

TIA-1 Is a Functional Prion-Like Protein Joseph B. Rayman and Eric R. Kandel

Molecular Genetics of Neurodegenerative Dementias

Flora I. Hinz and Daniel H. Geschwind

Cross- $\beta$ Polymerization of Low Complexity

Sequence Domains

Masato Kato and Steven L. McKnight

For additional articles in this collection, see http://cshperspectives.cshlp.org/cgi/collection/

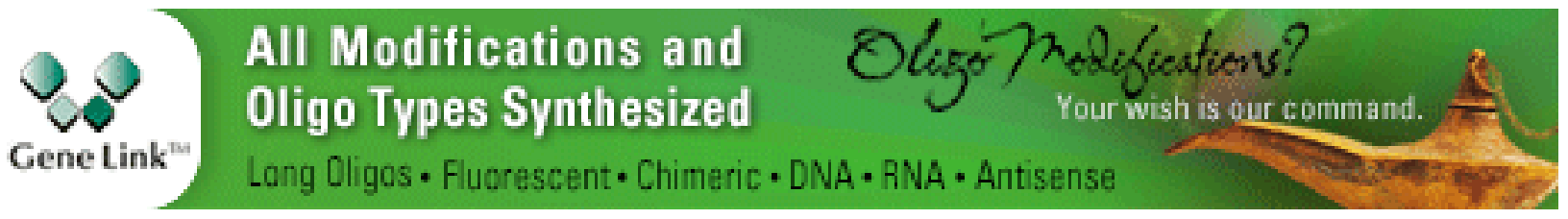

